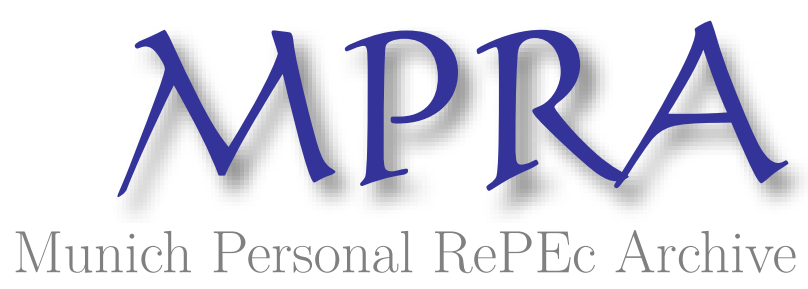

\title{
Commercialization of Intellectual Property (IP) for Small and Medium Enterprisers (SMEs) in India
}

\author{
Neeraj Parnami, Neeraj Parnami \\ Indian Institute of Technology Kharagpur, India
}

10 February 2008

Online at https://mpra.ub.uni-muenchen.de/8232/

MPRA Paper No. 8232, posted 12 Apr 2008 00:07 UTC 


\title{
Commercialization of Intellectual Property (IP) for Small and Medium Enterprisers (SMEs) in India
}

\author{
Neeraj Parnami \\ Rajiv Gandhi School Of Intellectual Property Law \\ Indian Institute of Technology - Kharagpur, Kharagpur - 721302
}

\begin{abstract}
Lots of people in this modern era take the Intellectual property (IP) as a magical word and they think that the game can be understood only by the experts or the trained people. Even there is no surprise that you may be asking yourself that why and how IP is going to provide an emerging platform in Small and Medium Enterprises (SMEs) sector? Presently, the Small and Medium Enterprises (SMEs) in India are at a crossroad and there is an intense debate over the questions like what would be the future of these SMEs? How these SMEs can survive in the international trade arena? What role can the government play in making these SMEs more competitive? How can the Intellectual property (IP) generate wealth in the business?

In order to know the answers of all these questions the paper is written and is concerned with the identification and analysis of current approaches of SMEs towards the Intellectual property (IP), the hurdles that they face; and the accessible \& feasible solutions.
\end{abstract}

Keywords: Intellectual Property, IP, Small and Medium Enterprisers, SMEs, Commercialization, Business Intelligence. 


\section{Paper Outline}

1. Introduction

2. Significance of Intellectual Property for Small and Medium Enterprisers (SMEs)

2.1 Intellectual Property and other assets in the business

2.2 Intellectual Property and Market Value of the business

3. Small and Medium Enterprisers (SMEs) sector in India

4. Hurdles before Small and Medium Enterprisers (SMEs)

5. Accessible \& feasible solutions

6. Conclusion

References

\section{Introduction}

Intellectual Property is a product of thought, creativity or an idea and every product or service that we use from morning till evening for example: toothbrush, mirror, cup-plate, motorcar, computer etc., is the result of an innovation. Today, their existence is possible because they are legally protected through the acquisition of IP rights. Intellectual Property (IP), in almost every aspect, may assist the SMEs in their business development \& competitive management strategy. For example: from product development to product design, from service delivery to marketing; and from raising financial resources to exporting or expanding their business abroad through licensing, franchising or through another technology transfer ways. Every entrepreneur in the industry has a unique recognition as a trademark or a brand name, which differentiates his / her business image from others business image. If anybody is using intellectual property (for example: patent, trademark etc.) that belongs to others, then it is strongly advised to him / her either to buy it or acquire it by licensing, assignment, cross-licensing etc. so as to avoid any disputes or expensive litigation issues in the future. In many countries like: India, Malaysia, Canada, 
UK, Australia etc., the Government provides encouragement and support to hightech start-ups and other innovative SMEs through grants, guarantees, subsidies or soft loan schemes, which are provided via various public funding institutions and banks that directly or indirectly recognize the importance of intellectual property assets.

\section{Significance of Intellectual Property for Small and Medium Enterprises ( SMEs )}

SMEs form the backbone of the Indian manufacturing sector and have become entrepreneurial engine of economic growth in India. It is estimated that about $70 \%$ of the employment growth comes from the SMEs in the Asian region and they account for almost $90 \%$ of industrial units in India and $40 \%$ of value addition in the manufacturing sector.

\subsection{Intellectual Property and other assets in the business}

The assets in the business may be largely divided into two classes: tangible assets i.e. physical assets - including buildings, machinery, financial assets \& infrastructure and intangible assets - ranging from Intellectual capital (IC) like creativity, innovation and know-how to ideas, brands, and designs. There is no doubt that the physical assets play very important role in any company to determine the competitiveness in the business arena but the intangible assets may play a bigger role and describe the potential value in the business. There are numerous examples in the industry as IBM, Aricent, Denso etc., where the data shows that the business value increases overnight as a result of acquisition of important patents in key technologies.

In order to acquire the IP rights SMEs may have following categories of intangible assets: 
- Patents and utility models for Innovative products and processes;

- Copyright and others related rights for cultural, artistic, literary works as well as for computer software;

- Trademarks for distinctive signs;

- Industrial Design rights for creative designs, including textile designs;

- Topographies of integrated circuits for microchips;

- Geographical Indication for goods of a given quality or reputation attributable to the geographical origin; and

- Trade secrets for the business secrets for commercial purpose.

\subsection{Intellectual Property and market value of the business}

There is always a demand of legally protected products / services in the business arena provided that the SMEs always take care of the protection, management and enforcement of the products / services. Than definitely IP becomes a valuable business asset. ${ }^{[1]}$

- IP rights may engender the revenue in the business through the licensing, sale, assignment or cross licensing.

- A potential patent / IP rights may open doors to a number of financing opportunities like: Private Investors, Venture Capitalists (VCs) or specialized banks towards SMEs and enhance their worth. At that time it becomes very important for the SMEs to have IP ownership to convince them for the commercialization of legally protected product / service in their business.

- IP assets may have great potential to raise the value of the business through M\&A, Joint Venture (JV) and Collaboration Schemes. 


\section{Small and Medium Enterprisers (SMEs) sector in India}

1. There are 12.8 million units (over 90 per cent of total industrial units) in the sector that employs nearly 31 million people.

2. The sector ${ }^{[2]}$ contributes nearly 39 per cent of the industrial production and 33 per cent of the exports.

3. The sector responded well to the initiatives by registering a growth rate of $11.7 \%$ in April-May 2007, which is far more impressive than their elder brothers in the manufacturing sector.

4. There are 6500 products ranging from traditional to high-tech items in the sector.

5. After agriculture, the sector provides the maximum employment i.e. 29.4 million people opportunities in the country.

6. The sector operates $99 \%$ in the debt Markets.

7. The sector holds great potential for further expansion and growth in the future.

\begin{tabular}{|l|l|l|l|l|l|l|l|}
\hline \multicolumn{7}{|c|}{ Table I : Performance of Micro and Small Enterprises } \\
\hline \multirow{2}{*}{ Year } & \multicolumn{2}{|c|}{ No. of Units (in Lakh) } & \multicolumn{2}{|c|}{$\begin{array}{l}\text { Production } \\
\text { (Rs. Crore) }\end{array}$} & $\begin{array}{l}\text { Employment } \\
\text { (in lakh) }\end{array}$ & $\begin{array}{l}\text { Exports } \\
\text { (Rs. } \\
\text { Crore) }\end{array}$ \\
\cline { 2 - 7 } & Regd. & Unregd. & Total & $\begin{array}{l}\text { At } \\
\text { current } \\
\text { prices }\end{array}$ & $\begin{array}{l}\text { At } \\
\text { constant } \\
\text { prices }\end{array}$ & & \\
\hline $\begin{array}{l}2002- \\
03\end{array}$ & 15.91 & 93.58 & $\begin{array}{l}109.49 \\
(4.1)\end{array}$ & $\begin{array}{l}118.59 \\
(4.1)\end{array}$ & $\begin{array}{l}2,10,636 \\
(7.7)\end{array}$ & $\begin{array}{l}260.21 \\
(4.4)\end{array}$ & $\begin{array}{l}86,013 \\
(20.7)\end{array}$ \\
\hline $\begin{array}{l}2003- \\
04\end{array}$ & 16.97 & 96.98 & $\begin{array}{l}113.95 \\
(4.1)\end{array}$ & $\begin{array}{l}118.59 \\
(4.1)\end{array}$ & $\begin{array}{l}2,10,636 \\
(7.7)\end{array}$ & $\begin{array}{l}271.42 \\
(4.3)\end{array}$ & $\begin{array}{l}97,644 \\
(13.5)\end{array}$ \\
\hline $\begin{array}{l}2004- \\
05\end{array}$ & 17.53 & 96.98 & $\begin{array}{l}118.59 \\
(4.1)\end{array}$ & $\begin{array}{l}4,18,263 \\
(16.9)\end{array}$ & $\begin{array}{l}2,51,511 \\
(10.0)\end{array}$ & $\begin{array}{l}282,57 \\
(4.1)\end{array}$ & $\begin{array}{l}1,24,417 \\
(27.4)\end{array}$ \\
\hline $\begin{array}{l}2005- \\
06\end{array}$ & 17.53 & 104.71 & $\begin{array}{l}118.59 \\
(4.1)\end{array}$ & $\begin{array}{l}4,76,201 \\
(13.9)\end{array}$ & $\begin{array}{l}2,77,668 \\
(10.4)\end{array}$ & $\begin{array}{l}294.91 \\
(4.4)\end{array}$ & N.A. \\
\hline
\end{tabular}

Note: Figures in parenthesis Indicate percentage growth over previous years ${ }^{[3]}$ Source: Development Commissioner (SSI) 


\section{Hurdles before Small and Medium Enterprises (SMEs)}

SMEs constitutes more than $90 \%$ of total number of industrial enterprises, but with the opening of trade borders and the loosening trade barriers, they are facing tough competition from their global counterparts due to liberalization, change in manufacturing strategies, technological changes in the business arena and that's why they are not able to learn and earn from the Intellectual Property. Some of the main hurdles are discussed here.

\section{1) Lack of awareness}

In India, many SMEs provide the raw material to large scale manufacturers and they do not realize the importance of Intellectual Property in the business, to protect their ideas and innovation of product; as they are mainly focused towards the production and operation of the raw material.

\section{2) Limited financial capital}

Financial is the most common problem when dealing with SMEs. They mainly focus towards their business with the available limited financial capital rather than the Intellectual Property issues as Intellectual Property is not considered the primary source to generate the revenue for their business. Simultaneously in order to compete their competitors; in case of launching a new product comprising advance technology, they prefer to spend the money in the business rather than in the Intellectual Property.

\section{3) Lack of technical knowledge}

It is said that technical skill is the road that leads to product innovation and Intellectual Property. In India, many SMEs operate their business without having sound technical knowledge to manufacture the product and that's why they can not even think about the Intellectual Property in their business. 


\section{4) Lack of Business Intelligence (BI)}

Business Intelligence $^{[4]}(\mathrm{BI})$ is the process of enhancing the data into meaningful information \& the meaningful information into knowledge. It may be one of the big hurdles for SMEs to think about their business deeply. Business Intelligence $(\mathrm{BI})$ enables the business to make well - informed business decisions, equipping them to understand the potential benefits and impacts involved. In the competitive and dynamic market scenario, SMEs need to implement every possible means to get an edge and effective decision-making process that has to be a well-informed process, and not a guessing game.

\section{Accessible \& feasible solutions}

In order to avoid the demarcation among the SMEs of India \& rest parts of the world, a continuous advancement and improvement within the SMEs is required. One of the best ways is - to provide them a sound knowledge of IP to make them able to take part in the economic race of the world through their ideas of innovation. In this context, the Indian government has initiated important steps towards SME sector to cultivate and enhance their capabilities and capacity in becoming resilient and competitive in global market by providing incentives in the form of grants and soft loans as well as development programmes.

The existing hurdles for SMEs can be resolved by:

1. Organizing workshops on various aspects of Intellectual Property.

2. Enhancing the SMEs accessibility to equity and other funds from the markets.

3. Enforcing the strongly implementation of IP strategy in the country.

4. Providing adequate information, orientation and facilities for protecting their Intellectual Property. 
5. Improving awareness on Intellectual Property amongst SMEs to develop a positive approach towards creation, protection and management of Intellectual Property (IP) as a source of creating a competitive edge in the trade and technology market for value addition.

6. Providing financial assistance such as grants, banking loans, doorstep banking from ICICl, HSBC banks etc. These banks can create a "credit scoring model" with high predictive power.

7. Providing Intellectual Property training.

\section{Conclusion:}

There is still requirement of drawing the pictures of efforts before filling the colors of Intellectual Property on the canvas. With the expansion of market and the growth of competition, SMEs will have to aim at Intellectual Property, Business Intelligence \& technical knowledge. Before ripping the fruits of Intellectual Property in the country, Intellectual Property organization is required to organize and promote such IP activities in the villages, towns as well as in the cities. The SMEs may become the potential sector in the country, if they are supported in the right direction by the Intellectual Property organizations. 


\section{References:}

1. http://www.wipo.int/sme/en/ip business/ip asset/sme market value.htm, Last visited on $4^{\text {th }}$ Jan. 2008.

2. Building Awareness on Intellectual Property Rights (IPR) for MSME in India Asian Regional Meet on IPR $13^{\text {th }}-14^{\text {th }}$ Dec. 2007, Jeju Island, Republic of Korea, Available on http://www.wipo.int/edocs/mdocs/sme/en/wipo smes cju 07/wipo smes cju 07 topic10 2.ppt\#272,1, Last visited on $8^{\text {th }}$ Jan. 2008.

3. K. D. Raju, RGSOIPL, IIT Kharagpur, "Small and Medium Enterprises in India", Available on http://papers.ssrn.com/ sol3/papers.cfm?abstract id $=1080505$, Last visited on $10^{\text {th }}$ Jan. 2008.

4. The Economic Times - News Paper, "The Intelligent Path Ahead", $15^{\text {th }}$ Jan. 2008.

5. The Economic Times - News Paper, "Do banks know their SME clients?" 16th Jan. 2008.

6. Protection of Intellectual Property and leveraging its strengths; IPR conference, $27^{\text {th }}$ Oct. 2007, Chandigarh, Punjab.

7. Mr. Lakshmi Kumaran, Business Owner of LAKSHMI KUMARAN \& SRIDHARAN, ESummit IPR conference, $25^{\text {th }}-26^{\text {th }}$ Aug. 2007, IIT Kharagpur, Kharagpur. 